\title{
Temporal changes in benthic assemblages on Florida Keys reefs 11 years after the 1997/1998 El Niño
}

\author{
R. R. Ruzicka ${ }^{1, *}$, M. A. Colella ${ }^{1}$, J. W. Porter ${ }^{2}$, J. M. Morrison $^{3}$, J. A. Kidney ${ }^{1}$, \\ V. Brinkhuis ${ }^{1}$, K. S. Lunz ${ }^{1}$, K. A. Macaulay ${ }^{1}$, L. A. Bartlett ${ }^{1}$, M. K. Meyers ${ }^{2}$, J. Colee $^{4}$ \\ ${ }^{1}$ Florida Fish and Wildlife Conservation Commission, Fish and Wildlife Research Institute, 100 8th Avenue SE, \\ Saint Petersburg, Florida 33701, USA \\ ${ }^{2}$ Odum School of Ecology, University of Georgia, 140 East Green Street, Athens, Georgia 30602, USA \\ ${ }^{3}$ US Geological Survey, St. Petersburg Coastal and Marine Science Center, 600 4th Street S, Saint Petersburg, Florida 33701, \\ USA \\ ${ }^{4}$ Institute of Food and Agricultural Services, University of Florida, 406 McCarty Hall C, PO Box 110339, Gainesville, \\ Florida 32611, USA
}

\begin{abstract}
Disturbances that result in the mass mortality of reef-building corals are changing the appearance of reefs worldwide. Many reefs are transitioning away from scleractinian-coraldominated assemblages to benthic communities composed primarily of non-scleractinian taxa. This study evaluated recovery patterns of reef communities in the Florida Keys following the mortality associated with the 1997/1998 El Niño. We examined temporal trends among the 5 most spatially abundant reef taxa and stony coral species from 1999 to 2009 at 3 spatial scales, and applied a Principal Coordinate Analysis (PCoA) to determine whether changes in their cover resulted in a shift in community structure. Trends of decreasing stony coral cover were not identified Keys-wide between 1999 and 2009, but 2 of the 3 habitats examined - shallow and deep forereefs-did show a significant decline in cover. Concomitantly, octocoral cover significantly increased Keys-wide and in all 3 habitats. The transition to octocorals was most evident on shallow forereefs, where octocoral cover significantly increased at 9 of 12 reefs and overwhelmingly influenced the PCoA. On deep forereefs, octocoral and sponge cover did significantly increase, but did not impart a clearly defined shift in community structure like that observed on shallow forereefs. Community composition at patch reefs was relatively consistent during the study, but the increase in octocoral cover may accelerate further following a cold-water mortality event in 2010. These results demonstrate that octocorals are emerging as the predominant benthic taxa in the Florida Keys. Although the transition to octocorals may have started long ago, their apparent resilience to present-day stressors will likely allow this shift to continue into the foreseeable future.
\end{abstract}

KEY WORDS: Coral reefs $\cdot$ Stony corals $\cdot$ Octocorals $\cdot$ Macroalgae $\cdot$ Phase shifts $\cdot$ Principal Coordinate Analysis

\section{INTRODUCTION}

Modern coral reefs are endangered due to a myriad of natural and anthropogenic stressors. Numerous global and local threats to reef-building corals have been documented. These include reduced growth and survival due to increasing ocean temper-

*Email: rob.ruzicka@myfwc.com atures and seawater acidity, habitat loss stemming from destructive fishing practices, food web imbalances facilitated by overfishing, sedimentation associated with agricultural and construction activities, and eutrophication and pathogen introduction due to watershed pollution and contamination (Hughes et al. 2003, Burke et al. 2011). Many of these stressors

(C) The authors and Fish \& Wildlife Research, Florida, Fish \& Wildlife Conservation Commission 2013. Open Access under Creative Commons by Attribution Licence. Use, distribution and reproduction are unrestricted. Authors and original publication must be credited.

Publisher: Inter-Research · www.int-res.com 
(e.g. overfishing and coastal development) have long historical precedents leading to chronic, systemic repercussions (Jackson et al. 2001, Pandolfi et al. 2003). Others have arisen and intensified more recently (e.g. mass stony coral bleaching events and disease outbreaks) and pose direct threats to stony corals (Harvell et al. 1999, Bruno et al. 2007, HoeghGuldberg et al. 2007). The cumulative effect of these stressors has been a worldwide degradation of coral reefs, with some reported to have lost more than half their scleractinian cover (Gardner et al. 2003, De'ath et al. 2012). There are instances of degraded reefs returning to a stony-coral-dominated state, but most are confined to the Indo-Pacific region (Connell 1997, Diaz-Pulido et al. 2009, Osborne et al. 2011). In the Caribbean, there is growing evidence that reefs are transitioning from benthic assemblages composed primarily of stony corals to assemblages dominated by non-scleractinian taxa (Norström et al. 2009, Roff \& Mumby 2012).

One of the most commonly accepted paradigms in coral reef ecology is that disturbances involving widespread stony coral mortality lead to 'phase shifts' in community structure (Done 1992, Hughes 1994). Generally, in the immediate aftermath of the disturbance, faster-growing, weedier species with high reproductive output colonize the space vacated by the long-lived, slow-growing, reef-building corals. The weedier species may become well-established and persist indefinitely, preventing a return to the original community state (Hughes 1994, Jackson et al. 2001, Rogers \& Miller 2006). The most frequently cited example for the Caribbean is the replacement of stony corals by fleshy macroalgae as the dominant taxa (Bruno et al. 2009, Dudgeon et al. 2010). However, other examples of weedy takeovers include small, encrusting sponges (Aronson et al. 2002) and smaller brooding corals like Porites astreoides (Green et al. 2008) and Agaricia tenuifolia (Aronson \& Precht 1997, Aronson et al. 2004). The term 'phase shift' implies a switch in the dominant organisms of a community (Petraitis \& Dudgeon 2004), but this term has not been well articulated because 'dominance' has often been poorly defined (Bruno et al. 2009). This misunderstanding has led to liberal use of 'phase shifts' to describe general decreases in stony coral cover and relative increases in the abundance of other taxa (Rogers \& Miller 2006, Bruno et al. 2009). In addition, many analyses do not quantify changes in the population structure of the entire community, instead focusing on a single taxonomic group (e.g. sponges or stony corals) or, at most, a pair of benthic constituents (e.g. stony corals and macroalgae). Frequently, these studies are limited in spatial and temporal resolution (e.g. have only a few study sites or a few years of data). Such limitations often result in misleading characterizations of the status of reefs (e.g. Pawlik 2011) because successional states can persist for prolonged periods and natural population fluctuations, irrespective of the larger reef community, can appear as phase shifts (Connell \& Slatyer 1977, Dudgeon et al. 2010).

Coral reefs of the Florida Keys are widely considered to be among the most heavily exploited in the world (Kruczynski \& McManus 1999, Johns et al. 2001), and provide a compelling environment to study changes in reef community structure. In the last $100 \mathrm{yr}$, serial overfishing has led to the collapse of once-prolific fisheries, including those of queen conchs, sponges, turtles, sharks, and groupers (Pandolfi et al. 2005, McClenachan 2009), and the urbanization of South Florida has disrupted natural water flow, increased pollution and terrestrial runoff, and intensified the recreational use of reefs by an order of magnitude (Lapointe \& Matzie 1996, Johns et al. 2001, Lipp et al. 2002). Reefs in the Florida Keys are also vulnerable to emerging threats associated with climate change, evident in the increasing regularity of warm-water-induced mass bleaching events in the past $30 \mathrm{yr}$ (Causey 2001, Wagner et al. 2010), and to the regional spread of marine pandemics, including the mass mortalities of the echinoid Diadema antillarum and the framework-building corals Acropora palmata and A. cervicornis (Lessios et al. 1984, Aronson \& Precht 2001). Although the Florida Keys have endured a long history of exploitation and pervasive environmental change, conservation actions have been implemented over the past 2 decades in an attempt to reverse the detrimental effects of overfishing and impaired water quality.

The primary goal of this study was to evaluate the response of benthic communities in the Florida Keys in the $11 \mathrm{yr}$ period following the 1997/1998 El NiñoSouthern Oscillation, a climatic pattern that induced extensive ocean warming and was responsible for mass scleractinian mortality worldwide during that period (Wilkinson 2000, Glynn \& Colley 2001). In the Florida Keys, coral bleaching and increased disease prevalence associated with this event reduced stony coral cover by $\sim 40 \%$ between 1996 and 1999 (Porter et al. 2001, Somerfield et al. 2008, Ruzicka et al. 2010). Other benthic groups were affected, with octocoral cover decreasing $\sim 25 \%$ and sponge cover decreasing $~ 38 \%$ (Harvell et al. 2001, Ruzicka et al. 2010). While a leading objective of this study was to determine whether stony corals demonstrated any 


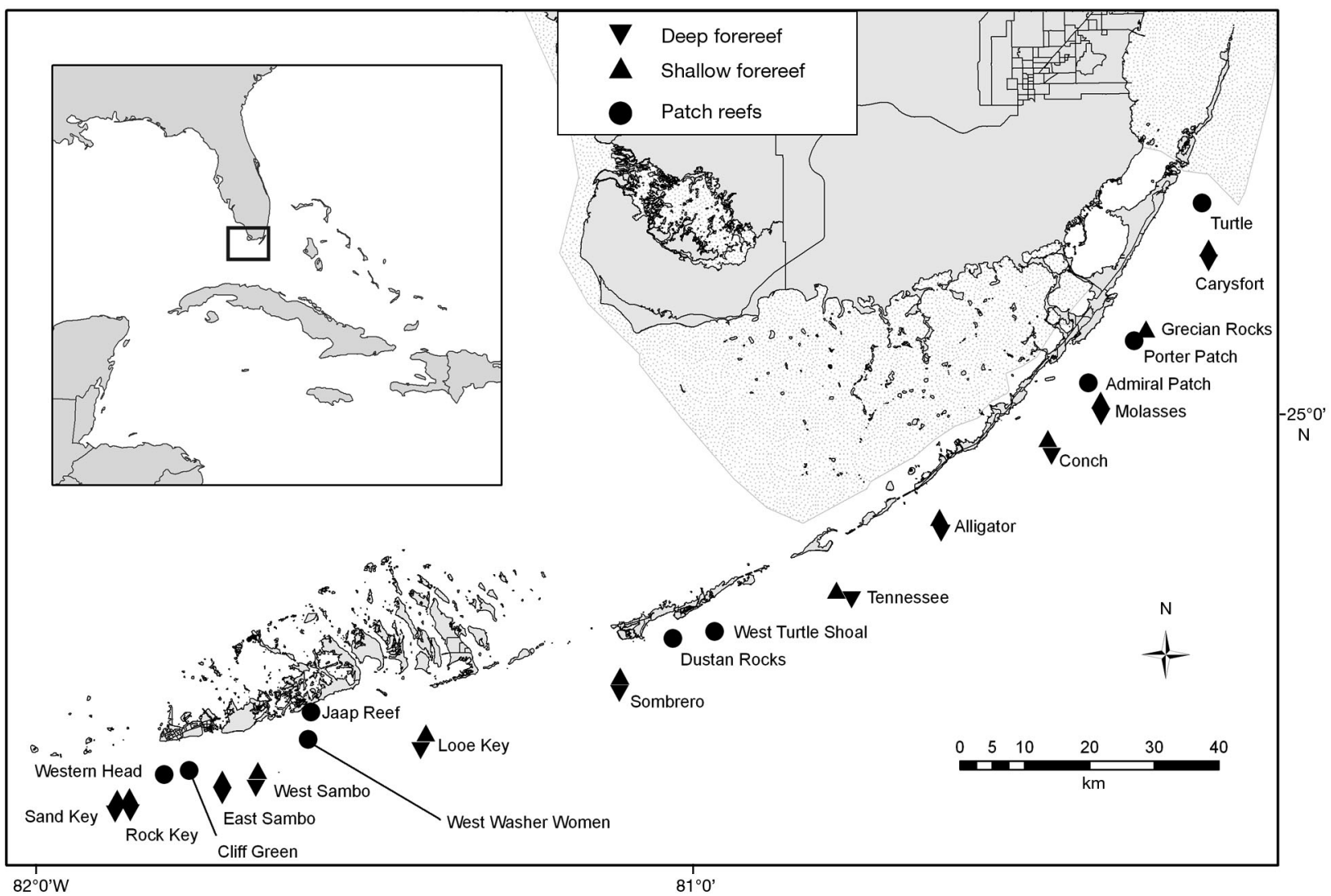

Fig. 1. The Florida Keys, showing the location of coral reef evaluation and monitoring project (CREMP) survey sites along the Florida Reef Tract. Shallow and deep forereef sites are paired except for Grecian Rocks, where only the shallow forereef is surveyed

recovery following this disturbance, it was equally pertinent to understand how the broader coral reef assemblage has responded. We examined benthic cover trends for 5 of the most common reef taxa (macroalgae, octocorals, sponges, stony corals, and zoanthids) and used multivariate analyses to assess whether temporal changes in their cover constituted a shift in community structure. Changes in scleractinian cover were further refined by evaluating the trends of 5 predominant stony coral species found on Florida Keys reefs. To distinguish localized changes from those occurring across the broader Florida Keys archipelago, benthic cover data were assessed at 3 spatial scales: by individual reef, reef type, and Keyswide. To date, the results presented here provide the most comprehensive assessment of changes occurring within the Florida Keys reef ecosystem.

\section{MATERIALS AND METHODS}

Since 1996, the Coral Reef Evaluation and Monitoring Project (CREMP) has conducted annual assess- ments every summer (May through August) at fixed sites to evaluate the status and trends of benthic communities in the Florida Keys (J. W. Porter et al. 2002, Somerfield et al. 2008). The present assessment focuses on results from 32 reefs, representing 3 predominant reef habitats ( 9 patch reefs, 12 shallow forereefs, and 11 deep forereefs) in the Florida Keys archipelago (Fig. 1). Despite study sites at deep and shallow forereefs sharing the same nomenclature, they were not co-located (e.g. along the same spur). Deep and shallow forereefs were separated by large expanses of sand and represented distinct ecological zones. Methods used by CREMP to estimate benthic cover are described in J. W. Porter et al. (2002) and Somerfield et al. (2008). In summary, 2 to 4 permanent stations were surveyed at each site. Three $22 \mathrm{~m} \times$ $40 \mathrm{~cm}$ transects were filmed with a Sony Handycam DCR-TRV900 video camera at every station. For each station, an average of 200 abutting images were extracted from the video. Random points were generated for each image and analyzed in a custom software package (Point Count'99). Stony corals were identified to species and other benthic organisms to gross taxo- 
nomic levels (macroalgae, octocorals [Order Alcyonacea], sponges, and zoanthids). Octocoral cover included both benthic cover (e.g. encrusting species such as Briareum asbestinum and Erythropodium caribaeorum) and canopy cover (branching species). During image analysis, points that fell on a branch of an octocoral were recorded as 'octocoral,' even if those branches may have obscured other sessile organisms. Identification of macroalgae followed definitions used by Steneck (1988) and included all fleshy, filamentous, and calcareous forms with recognizable structure (e.g. Halimeda spp., Dictyota spp., Lobophora spp.). Turf algae and crustose coralline algae were not recorded as macroalgae (Steneck 1988).

Since the goal of this study was to evaluate changes in the benthic communities following the 1997/1998 El Niño, data obtained before 1999 are presented for illustrative purposes but were omitted from statistical appraisals. The year 1999 was selected as the starting point for the analysis because most of the acute mortality directly associated with the 1997/1998 El Niño had abated, and stony coral cover had increased slightly between 1999 and 2000 (see Fig. 2). We chose 2009 as the end point because catastrophic mortality occurred in January 2010 during a record breaking cold-weather event (Kemp et al. 2011, Lirman et al. 2011, Colella et al. 2012).

\section{Univariate trends}

Trends in benthic cover were estimated using a linear mixed model in SAS ${ }^{\circledR}$ v9.2 for 5 reef taxa (macroalgae, octocorals, sponges, stony corals, and zoanthids) and 5 predominant stony coral species (Colpophyllia natans, Orbicella annularis complex [formerly Montastraea \{Budd et al. 2012\} and includes $O$. annularis, O. faveolata, and O. franksi; hereafter referred to as $O$. annularis], $M$. cavernosa, Porites astreoides, and Siderastrea siderea). Cumulatively, the 5 groups represent at least $95 \%$ of the living biotic cover on reefs in the Florida Keys, while the 5 scleractinian species have contributed to $>80 \%$ of the total stony coral cover annually since 1999 . Before 1999, the contribution of these 5 scleractinian species to total stony coral cover was lower ( 60 to $70 \%$ ) because Acropora palmata and Millepora complanata were still present on some shallow forereefs. After the 1997/1998 El Niño, absolute cover for both A. palmata and M. complanata fell to $<0.2 \%$, and as a result, both species were ill-suited for trend analyses. Trends in benthic cover were examined at 3 levels: (1) for individual sites with stations as replicates
( $\mathrm{N}=2$ to 4 stations per site), (2) by habitat, with the data averaged for all sites within each reef type $(\mathrm{N}=$ 11 deep forereefs, $N=12$ shallow forereefs, $N=9$ patch reefs), and (3) Keys-wide, with data averaged for all sites $(\mathrm{N}=32)$. Station data were nested within sites for habitat and Keys-wide analyses.

For all trend analyses (individual reef, habitat, and Keys-wide) a linear regression was calculated using annual percent cover data from 1999 through 2009. Prior to analysis, percent cover data was square-root transformed. Because the dataset was based on a repeated-measures design, several covariance and autocorrelation parameters were tested to account for temporal and spatial effects that could result in overestimation of linear trends (Burnham \& Anderson 2002). A first-order autoregressive covariance structure yielded the best fit and incorporated more variance into the model than other covariance settings. To reduce spatial autocorrelation effects due to the repeated sampling of permanent transects, the effect of reef within year was randomized (Sweatman et al. 2011). Because mean cover for some benthic groups was disproportional across the 3 habitats, a random intercept was added to the Keys-wide model to normalize differences in cover. Model estimation of the change in percent cover per year $( \pm$ SE) was generated from the least square means in the model. A 2sided $t$-test was used to determine whether the slope of the regression was significantly different from zero. Model residuals met all assumptions for normality and homogeneous variance. For the trend analysis of individual reefs, a post hoc Bonferroni adjustment $(\mathrm{p}<$ 0.002 ) was used to determine significance in order to reduce the possibility of Type I error due to the repeated testing of the same response variable. Lower statistical power and the Bonferroni correction limited the number of individual reefs for which a significant trend in cover was identified. A p-value adjustment was not applied to habitat or Keys-wide analyses.

\section{Multivariate analyses}

To evaluate whether significant changes in cover estimated from the linear models yielded a shift in reef community structure, a Principal Coordinate Analysis (PCoA) using Bray-Curtis dissimilarity was performed in PRIMER 6 (Clarke \& Gorley 2006). Percent cover data for the 5 benthic cover variables (macroalgae, octocorals, sponges, stony corals, and zoanthids) were square-root transformed and averaged for each habitat and year from 1999 through 2009. Vector plots were overlaid on PCoA ordinations 


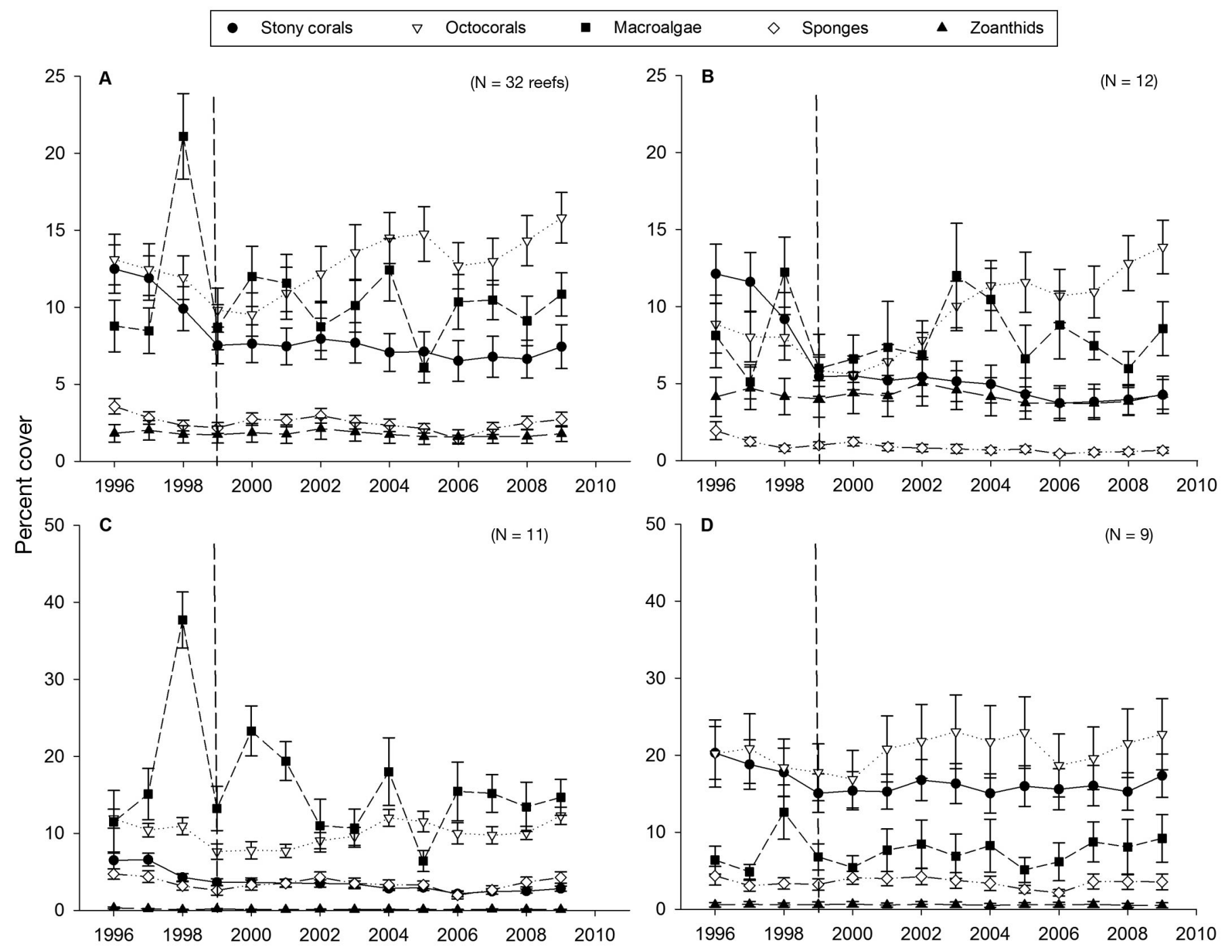

Fig. 2. Annual percent cover (mean \pm SE) of 5 benthic taxonomic groups from 1996 to 2009 for (A) Keys-wide, (B) shallow forereefs, (C) deep forereefs and (D) patch reefs. Dashed line indicates 1999 baseline after acute mortality during the 1997/1998 El Niño had abated. Corresponding linear trends estimating the change in percent cover per year for the 5 benthic groups are listed in Table 1. Note: scale of $y$-axis for graphs A \& B differ from graphs C \& D

using multiple partial correlations between the 5 benthic variables and the PCoA axes. This method ensured that correlation coefficients used to produce the vector plots considered all variables simultaneously, as opposed to Pearson or Spearman coefficients, in which response variables are correlated independently. The PCoA analyses were derived for each habitat separately because differences in community structure across habitats were more pronounced than annual changes within habitats, making temporal trends less discernible in a single ordination. For all reef types, the first $2 \mathrm{PCoA}$ axes explained $>80 \%$ of the variance, justifying their use to summarize changes in community structure.

\section{RESULTS}

Stony corals demonstrated little to no recovery between 1999 and 2009 (Fig. 2). While no Keys-wide decrease in stony coral cover was observed, significant declines were found at deep and shallow forereefs (Table 1). Cover declined in these 2 habitats from $5.4 \pm 1.3 \%( \pm \mathrm{SE})$ to $4.3 \pm 1.2 \%$ and from $3.6 \pm$ $0.5 \%$ to $2.8 \pm 0.3 \%$, respectively, between 1999 and 2009 (Fig. 2). Patch reefs, which generally have the highest stony coral cover of any reef type in the Florida Keys, were unchanged throughout the period, fluctuating between 15 and $17 \%$ cover annually (Fig. 2). Of the 32 sites assessed here, 31 did not 
Table 1. Model estimation of change in percent cover per year $( \pm \mathrm{SE})$ for the 5 taxonomic groups and 5 most spatially common stony coral species in the Florida Keys from 1999 to 2009. Linear trends correspond with time series presented in Figs. 2 \& 3. Model estimation of the change in percent cover per year was calculated from a generalized linear mixed model in SASß v9.2. Significant trends in cover (denoted in bold) — increasing $(\uparrow)$, decreasing $(\downarrow)$, or unchanged $(\leftrightarrow)$ — were identified with a 2sided $t$-test that identified the rate of change as significantly different from zero. $\mathrm{K}=$ Keys-wide trend $(\mathrm{N}=32$ reefs); $\mathrm{D}=$ deep forereefs $(\mathrm{N}=11), \mathrm{S}=$ shallow forereefs $(\mathrm{N}=12), \mathrm{P}=$ patch reefs $(\mathrm{N}=9)$. Minimum and maximum percent cover values and corresponding years provided

\begin{tabular}{|c|c|c|c|c|c|c|c|c|}
\hline Variable & Habitat & Estimate $\pm \mathrm{SE}$ & $\mathrm{df}$ & $t$ & $\mathrm{p}$ & Trend & Max(Year) & Min(Year) \\
\hline \multirow[t]{4}{*}{ Stony coral } & $\mathrm{K}$ & $-0.147 \pm 0.077$ & 921.6 & -1.895 & 0.058 & $\leftrightarrow$ & $7.9(2002)$ & $6.5(2006)$ \\
\hline & D & $-0.288 \pm 0.143$ & 899.3 & -2.012 & 0.045 & $\downarrow$ & $3.6(1999)$ & $2.1(2006)$ \\
\hline & $\mathbf{S}$ & $-0.313 \pm 0.118$ & 931.6 & -2.651 & 0.008 & $\downarrow$ & $5.5(2000)$ & $3.7(2006)$ \\
\hline & $\mathrm{P}$ & $0.244 \pm 0.144$ & 922.6 & 1.694 & 0.091 & $\leftrightarrow$ & 17.3(2009) & $15.0(2004)$ \\
\hline \multirow[t]{4}{*}{ Octocoral } & $\mathbf{K}$ & $0.971 \pm 0.120$ & 953.5 & 8.098 & $<0.001$ & $\uparrow$ & 15.8(2009) & $9.5(2000)$ \\
\hline & D & $0.698 \pm 0.219$ & 927.1 & 3.186 & 0.001 & $\uparrow$ & $12.3(2009)$ & $7.6(1999)$ \\
\hline & $\mathbf{S}$ & $1.429 \pm 0.182$ & 960.7 & 7.853 & $<0.001$ & $\uparrow$ & $13.9(2009)$ & $5.6(2000)$ \\
\hline & $\mathbf{P}$ & $0.571 \pm 0.222$ & 951.8 & 2.577 & 0.010 & $\uparrow$ & $23.0(2003)$ & $16.9(2000)$ \\
\hline \multirow[t]{4}{*}{ Macroalgae } & $\mathrm{K}$ & $0.231 \pm 0.236$ & 438.9 & 0.980 & 0.328 & $\leftrightarrow$ & $12.4(2004)$ & $6.1(2005)$ \\
\hline & $\mathrm{D}$ & $-0.339 \pm 0.397$ & 424.8 & -0.854 & 0.394 & $\leftrightarrow$ & $23.3(2000)$ & $6.4(2005)$ \\
\hline & $\mathrm{S}$ & $0.555 \pm 0.346$ & 455.8 & 1.605 & 0.109 & $\leftrightarrow$ & $12.0(2003)$ & $6.0(2008)$ \\
\hline & $\mathrm{P}$ & $0.325 \pm 0.415$ & 452.1 & 0.784 & 0.433 & $\leftrightarrow$ & $9.2(2009)$ & $5.1(2005)$ \\
\hline \multirow[t]{4}{*}{ Sponge } & $\mathrm{K}$ & $-0.013 \pm 0.088$ & 521.9 & -0.148 & 0.882 & $\leftrightarrow$ & $3.0(2002)$ & $1.4(2006)$ \\
\hline & D & $0.325 \pm 0.163$ & 511.6 & 1.999 & 0.046 & $\uparrow$ & $4.3(2002)$ & $2.0(2006)$ \\
\hline & $\mathrm{S}$ & $-0.223 \pm 0.135$ & 525.3 & -1.651 & 0.099 & $\leftrightarrow$ & $1.2(2000)$ & $0.4(2006)$ \\
\hline & $\mathrm{P}$ & $-0.045 \pm 0.164$ & 522.0 & -0.275 & 0.783 & $\leftrightarrow$ & $4.2(2002)$ & $2.1(2006)$ \\
\hline \multirow[t]{4}{*}{ Zoanthid } & K & $-0.003 \pm 0.066$ & 923.9 & -0.044 & 0.965 & $\leftrightarrow$ & $2.1(2002)$ & $1.6(2006)$ \\
\hline & $\mathrm{D}$ & $-0.060 \pm 0.124$ & 904.5 & -0.481 & 0.631 & $\leftrightarrow$ & $0.2(1999)$ & $0.1(2001)$ \\
\hline & $\mathrm{S}$ & $0.044 \pm 0.102$ & 931.2 & 0.430 & 0.667 & $\leftrightarrow$ & $5.0(2002)$ & $3.7(2006)$ \\
\hline & $\mathrm{P}$ & $-0.015 \pm 0.124$ & 923.8 & -0.122 & 0.903 & $\leftrightarrow$ & $0.6(2000)$ & $0.5(2008)$ \\
\hline \multirow[t]{4}{*}{ Colpophyllia natans } & $\mathrm{K}$ & $-0.017 \pm 0.057$ & 738.3 & -0.308 & 0.758 & $\leftrightarrow$ & $0.5(2002)$ & $0.3(2008)$ \\
\hline & $\mathrm{D}$ & $-0.060 \pm 0.106$ & 725.3 & -0.570 & 0.569 & $\leftrightarrow$ & $0.2(1999)$ & $0.1(2006)$ \\
\hline & $\mathrm{S}$ & $-0.041 \pm 0.087$ & 742.2 & -0.468 & 0.640 & $\leftrightarrow$ & $0.1(2001)$ & $0.1(2006)$ \\
\hline & $\mathrm{P}$ & $0.061 \pm 0.106$ & 737.8 & 0.569 & 0.570 & $\leftrightarrow$ & $1.7(2002)$ & $1.1(2008)$ \\
\hline \multirow[t]{4}{*}{ Orbicella annularis } & $\mathbf{K}$ & $-0.224 \pm 0.085$ & 920.4 & -2.640 & 0.008 & $\downarrow$ & $3.0(1999)$ & $2.4(2008)$ \\
\hline & D & $-0.483 \pm 0.157$ & 901.0 & -3.072 & 0.002 & $\downarrow$ & $1.4(1999)$ & $0.5(2008)$ \\
\hline & $\mathrm{S}$ & $-0.196 \pm 0.129$ & 928.2 & -1.516 & 0.130 & $\leftrightarrow$ & $2.4(2001)$ & $1.7(2008)$ \\
\hline & $\mathrm{P}$ & $-0.002 \pm 0.158$ & 920.7 & -0.012 & 0.991 & $\leftrightarrow$ & $6.5(2009)$ & $5.2(2000)$ \\
\hline \multirow[t]{4}{*}{ Montastraea cavernosa } & $\mathrm{K}$ & $-0.086 \pm 0.065$ & 917.8 & -1.316 & 0.189 & $\leftrightarrow$ & $1.5(2002)$ & $1.2(2008)$ \\
\hline & $\mathrm{D}$ & $-0.145 \pm 0.121$ & 898.6 & -1.194 & 0.233 & $\leftrightarrow$ & $0.5(2002)$ & $0.2(2008)$ \\
\hline & $\mathrm{S}$ & $-0.087 \pm 0.100$ & 925.0 & -0.868 & 0.386 & $\leftrightarrow$ & $0.2(2003)$ & $0.1(2008)$ \\
\hline & $\mathrm{P}$ & $-0.024 \pm 0.122$ & 917.7 & -0.199 & 0.842 & $\leftrightarrow$ & $4.5(2002)$ & $3.6(2004)$ \\
\hline \multirow{4}{*}{ Porites astreoides } & $\mathrm{K}$ & $0.024 \pm 0.059$ & 746.6 & 0.397 & 0.691 & $\leftrightarrow$ & $0.7(2002)$ & $0.5(2007)$ \\
\hline & $\mathrm{D}$ & $0.100 \pm 0.111$ & 734.8 & 0.899 & 0.369 & $\leftrightarrow$ & $0.2(2003)$ & $0.2(2000)$ \\
\hline & $\mathrm{S}$ & $-0.061 \pm 0.091$ & 750.0 & -0.672 & 0.502 & $\leftrightarrow$ & $1.1(2002)$ & $0.7(2007)$ \\
\hline & $\mathrm{P}$ & $0.074 \pm 0.111$ & 746.2 & 0.665 & 0.506 & $\leftrightarrow$ & $0.8(2002)$ & $0.5(1999)$ \\
\hline \multirow[t]{4}{*}{ Siderastrea siderea } & $\mathrm{K}$ & $0.069 \pm 0.058$ & 650.4 & 1.185 & 0.236 & $\leftrightarrow$ & $1.1(2002)$ & $0.9(2003)$ \\
\hline & $\mathrm{D}$ & $-0.039 \pm 0.108$ & 639.6 & -0.360 & 0.719 & $\leftrightarrow$ & $0.7(1999)$ & $0.6(2004)$ \\
\hline & $\mathrm{S}$ & $0.061 \pm 0.089$ & 653.1 & 0.688 & 0.492 & $\leftrightarrow$ & $0.4(2002)$ & $0.3(2004)$ \\
\hline & $\mathrm{P}$ & $0.191 \pm 0.109$ & 649.6 & 1.746 & 0.081 & $\leftrightarrow$ & $2.7(2002)$ & $2.1(2003)$ \\
\hline
\end{tabular}

show a change in cover, while cover at a single deep forereef significantly declined (Table 2). No reefs indicated a positive trend in stony coral cover between 1999 and 2009.

Declines in stony coral cover were associated with the mortality of the massive, framework-building coral Orbicella annularis. O. annularis can be abundant in all 3 reef habitats and is the spatially dominant stony coral in the Florida Keys (Fig. 3). Keys- wide, cover of $O$. annularis significantly declined between 1999 and 2009 (Table 1). Most notable was the steady loss at deep forereefs, where cover declined from $1.4 \pm 0.3 \%( \pm \mathrm{SE})$ in 1999 to $0.6 \pm 0.2 \%$ in 2009 (Fig. 3). Already low at project inception on deep forereefs, $O$. annularis cover has been reduced to a quarter of its 1996 value. A decline was also evident on shallow forereefs (Fig. 3), but its highly variable distribution in this habitat precluded the detec- 
Table 2. Number of sites in which benthic cover of 5 taxonomic groups and the 5 most spatially common stony coral species has significantly increased $(\uparrow)$, decreased $(\downarrow)$, or remained unchanged $(\leftrightarrow)$ in the Florida Keys from 1999 through 2009 . The linear trend for each benthic group or coral species at each site was calculated from a generalized linear mixed model (df varies) in SAS® v9.2. A Bonferroni correction $(p=0.002)$ was applied to determine significance of trends at individual sites

\begin{tabular}{|c|c|c|c|c|c|c|c|c|c|c|c|c|}
\hline \multirow[b]{2}{*}{ Variable } & \multicolumn{3}{|c|}{$\begin{array}{l}\text { Deep forereefs } \\
(N=11)\end{array}$} & \multicolumn{3}{|c|}{$\begin{array}{l}\text { Shallow forereefs } \\
\qquad(N=12)\end{array}$} & \multicolumn{3}{|c|}{$\begin{array}{c}\text { Patch reefs } \\
(\mathrm{N}=9)\end{array}$} & \multicolumn{3}{|c|}{$\begin{array}{c}\text { Total reefs } \\
(\mathrm{N}=32)\end{array}$} \\
\hline & $\uparrow$ & $\downarrow$ & $\leftrightarrow$ & $\uparrow$ & $\downarrow$ & $\leftrightarrow$ & $\uparrow$ & $\downarrow$ & $\leftrightarrow$ & $\uparrow$ & $\downarrow$ & $\leftrightarrow$ \\
\hline Stony coral & 0 & 1 & 10 & 0 & 0 & 12 & 0 & 0 & 9 & 0 & 1 & 31 \\
\hline Octocoral & 1 & 0 & 10 & 9 & 0 & 3 & 1 & 0 & 8 & 11 & 0 & 21 \\
\hline Macroalgae & 1 & 1 & 9 & 1 & 0 & 11 & 0 & 0 & 9 & 2 & 1 & 29 \\
\hline Sponge & 0 & 0 & 11 & 0 & 0 & 12 & 0 & 1 & 8 & 0 & 1 & 31 \\
\hline Zoanthid & 0 & 0 & 11 & 0 & 1 & 11 & 0 & 0 & 9 & 0 & 1 & 31 \\
\hline Colpophyllia natans & 0 & 0 & 11 & 0 & 0 & 12 & 0 & 0 & 9 & 0 & 0 & 32 \\
\hline Orbicella annularis & 0 & 1 & 10 & 0 & 0 & 12 & 0 & 0 & 9 & 0 & 1 & 31 \\
\hline Montastraea cavernosa & 0 & 0 & 11 & 0 & 0 & 12 & 0 & 0 & 9 & 0 & 0 & 32 \\
\hline Porites astreoides & 0 & 0 & 11 & 0 & 0 & 12 & 0 & 0 & 9 & 0 & 0 & 32 \\
\hline Siderastrea siderea & 0 & 0 & 11 & 0 & 0 & 12 & 0 & 0 & 9 & 0 & 0 & 32 \\
\hline
\end{tabular}

tion of significant trends. Conversely, O. annularis cover did not decline at patch reefs, remaining consistent at $5.7 \pm 0.1 \%$ (Fig. 3). Similar to the linear trends for combined stony coral cover, 31 of 32 reefs did not indicate a trend in $O$. annularis complex cover, but one deep forereef showed a decline. The 4 other greatest contributors to total stony coral cover in the Florida Keys, Colpophyllia natans, Montastraea cavernosa, Porites astreoides, and Siderastrea siderea, did not demonstrate any significant trends Keys-wide, within habitats, or at the site level (Table 1).

Octocorals were more resilient than other benthic groups in the Florida Keys. Octocoral cover significantly increased in all 3 habitats, and Keys-wide from 1999 through 2009 (Table 1). Increases in octocoral cover occurred every year except from 2005 to 2006, when a record number of hurricanes impacted the region in an 18 month span (Porter et al. 2012). Keys-wide, octocoral cover reached $15.8 \pm 1.6 \%$ $( \pm$ SE) in 2009 , the greatest value ever measured by our program (Fig. 2). The largest increase occurred on shallow forereefs, where average octocoral cover more than doubled, from $5.8 \pm 1.0 \%$ to $13.8 \pm 1.7 \%$, and cover at 9 of the 12 reefs significantly increased (Table 2). In all, cover increased at 11 of 32 sites and was unchanged for the other 21 (Table 2).

Macroalgae has been the most variable biotic component in the Florida Keys (Fig. 2). No significant changes in macroalgal cover were detected Keys-wide or by habitat between 1999 and 2009 (Table 1). Reef-specific trends were identified but appeared independent of one another. One shallow forereef and one deep forereef increased in cover, while a single deep forereef decreased (Table 2). Macroalgal cover at the other 29 reefs was unchanged. Annual Keys-wide macroalgal cover averaged $10.1 \pm 0.5 \%$ $( \pm \mathrm{SE})$, with the greatest cover occurring on the deep forereefs $(14.6 \pm 1.4 \%)$.

Zoanthids primarily occupied shallow forereefs, while sponges were more abundant on deep forereefs and patch reefs (Fig. 2). Keys-wide, significant trends in cover were not detected for either group (Table 1), but an increasing trend in sponge cover was observed on deep forereefs (Table 1). For both groups, 31 of 32 reefs did not show a significant trend in cover. Zoanthid cover decreased at a shallow forereef and sponge cover decreased at 1 patch reef (Table 2).

Patterns identified in the linear trend models were mostly corroborated by the PCoA. Octocorals and macroalgae were the prevailing constituents that influenced the first 2 principal coordinate axes in all 3 habitats (Table 3). The most apparent change in

Table 3. Multiple partial correlation coefficients produced by PRIMER for the 5 benthic variables used in the Principal Coordinate Analysis. Values indicate how well each variable correlates with each of the principal coordinate axes and are used to produce the vector plots illustrated in Fig. 4

\begin{tabular}{|lrrrrrr|}
\hline & \multicolumn{2}{c}{$\begin{array}{c}\text { Shallow foreefs } \\
\text { Variable }\end{array}$} & Axis 1 & Axis 2 & Deep forereefs & \multicolumn{2}{c|}{ Patch reefs } \\
& & & & Axis 2 & Axis 1 & Axis 2 \\
\hline Macroalgae & -0.2980 & 0.9086 & 0.8867 & 0.2402 & -0.6972 & 0.4906 \\
Octocoral & -0.8513 & -0.1905 & -0.4234 & 0.5672 & -0.6387 & -0.6693 \\
Sponge & 0.1908 & 0.0250 & -0.0891 & -0.4085 & -0.2555 & 0.5091 \\
Stony coral & 0.3625 & 0.1943 & 0.0497 & -0.6490 & -0.1737 & -0.1961 \\
Zoanthid & 0.1263 & 0.2787 & 0.0377 & 0.0308 & 0.0523 & 0.0796 \\
Variance explained & $69.8 \%$ & $23.1 \%$ & $55.3 \%$ & $25.9 \%$ & $58.9 \%$ & $27.4 \%$ \\
\hline
\end{tabular}



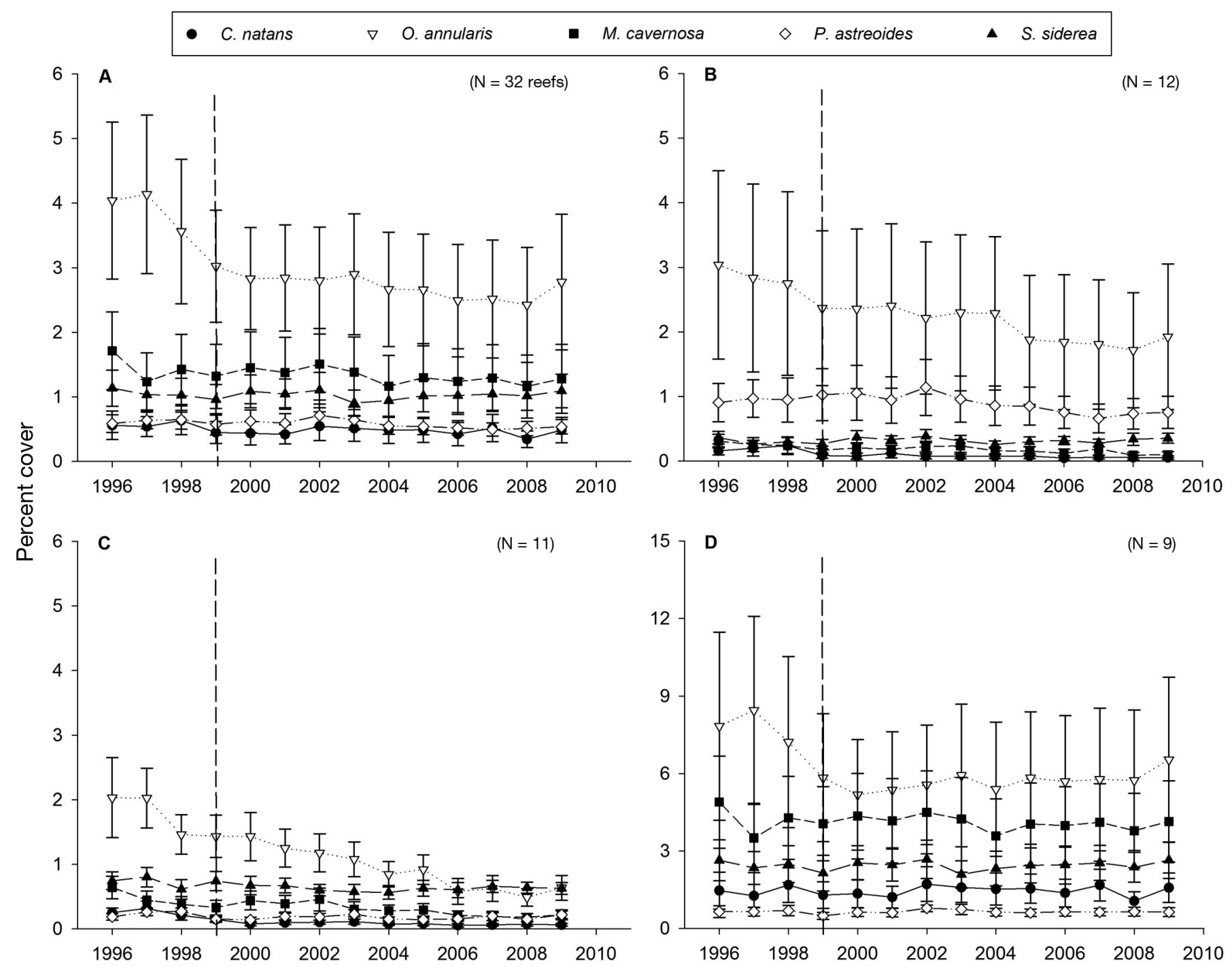

Fig. 3. Annual percent cover (mean \pm SE) of the 5 most spatially common stony corals from 1996 to 2009 for (A) Keys-wide, (B) shallow forereefs, (C) deep forereefs and (D) patch reefs. Dashed line marks 1999 baseline after acute mortality during the 1997/1998 El Niño had abated. Corresponding linear trends estimating the change in percent cover per year for the 5 coral species are listed in Table 1. Note: scale of $y$-axis for graphs A, B, \& C differ from graph D

community structure was on shallow forereefs. Octocorals were strongly and negatively correlated with the first axis, which explained $69.8 \%$ of the total variance in the analysis (Table 3). Macroalgae was strongly but positively correlated with the second axis, which accounted for $23.1 \%$ of the variance (Table 3 ). Stony corals were also correlated with the first axis, but the strength of this correlation was much weaker than for octocorals (Table 3), and the vector pointed in the opposite direction. Decreasing principal coordinate scores along the first axis from 1999 through 2009 support the notion that octocorals have become the primary component of the shallow forereef assemblage, while stony corals continued to decline (Fig. 4A). Macroalgal cover, as indicated by its strong correlation with the second axis, is clearly an important constituent of the ordination, but this was due more to its annual variability than to a directional shift through time.

The change in community structure at deep forereefs was less conspicuous than that at shallow forereefs. The first axis, which encapsulated $55.3 \%$ of the total variance, was linked to macroalgae and octocorals, but they were inversely correlated. The second axis, which accounted for $25.9 \%$ of the variance, was mostly associated with stony corals, octocorals, and sponges (Table 3). While the pattern at deep sites is partially obscured by high and fluctuating macro- 

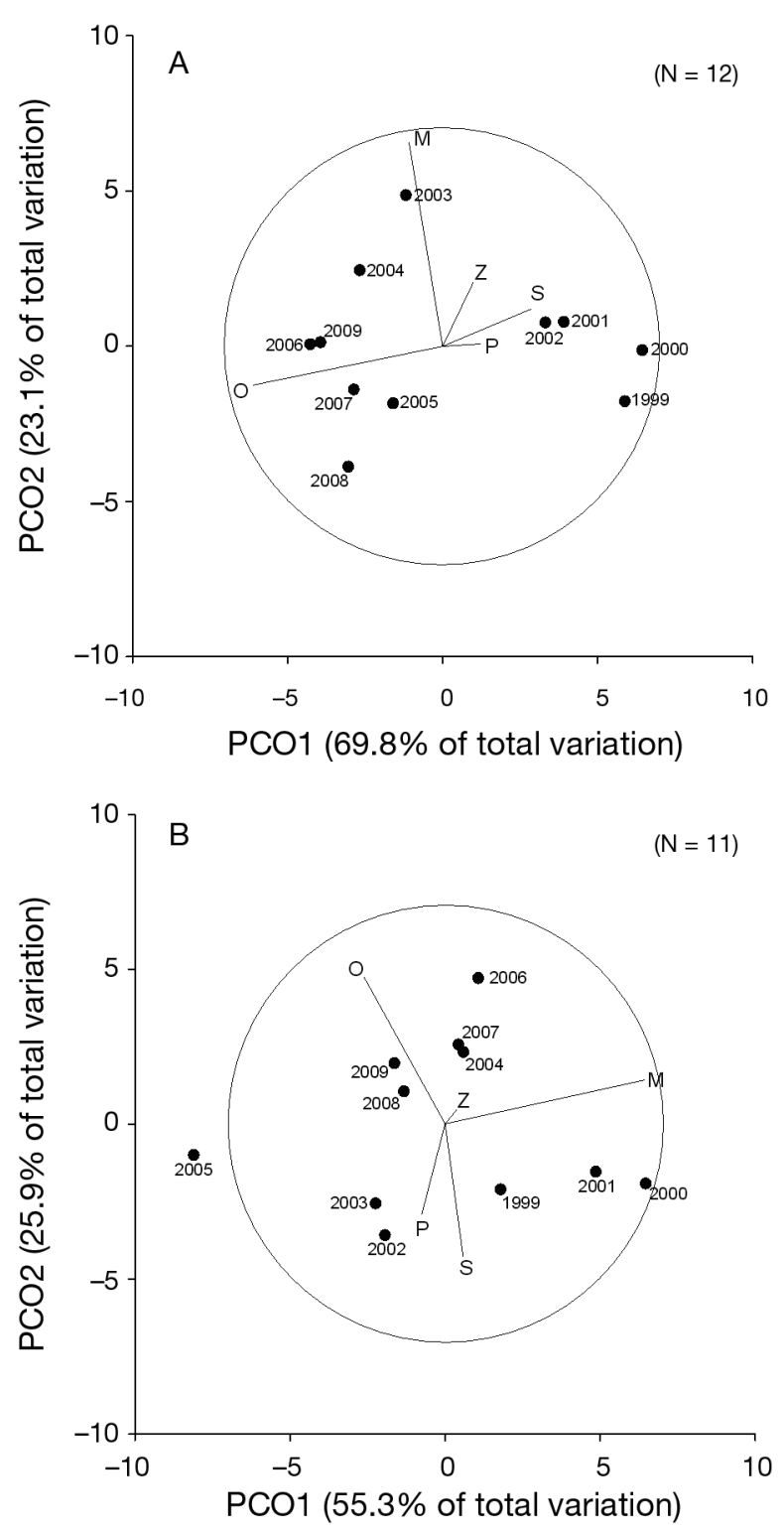

algal abundance, decreasing coordinate scores along the first axis from 1999 through 2009 indicate diminishing macroalgal cover and a slight increase in octocoral cover. Increasing coordinate scores along the second axis illustrate a transition to an assemblage with greater octocoral cover and lower stony coral cover (Fig. 4B). Although a trend of increasing sponge cover was detected for deep forereefs from the linear models (Table 1), it had only a minor influence on the overall community arrangement (Fig. 4B).

No clear temporal pattern was identified at patch reefs. The first axis, which accounted for $58.9 \%$ of the variance, was equally correlated between macroalgae and octocorals (Table 3). The second axis, which explained $27.4 \%$ of the variance, was mostly influenced by octocorals but also, to a lesser extent, by sponges and macroalgae (Table 3 ). The annual ordination scores were clustered in the center of the plot, signifying that the benthic assemblage on patch reefs changed little during the study period (Fig. 4C). This also suggests that the increase in octocoral cover identified from the linear model was subtle and did not impart a major influence on community structure.

\section{DISCUSSION}

Coral reefs are in a state of transition in the Florida Keys. In the 11 yr following the 1997/1998 El Niño, stony corals showed little recovery and continued to be a dwindling part of the benthic assemblage at deep and shallow forereefs (Fig. 4). Total stony coral cover, as well as the cover of the 5 species examined, did not significantly increase in any reef or habitat, or Keys-wide. The declines in stony coral cover at the deep forereefs can be attributed to the continued loss of the dominant, framework-building coral Orbicella annularis. A negative trajectory for $O$. annularis cover was documented at deep forereefs, and a broader pattern of decline across the Keys was also confirmed (Table 1). While mass bleaching events, such as the 1997/1998 El Niño, resulted in substantial

Fig. 4. Principal Coordinate Analysis ordination plots for (A) shallow forereefs, (B) deep forereefs and (C) patch reefs in the Florida Keys from 1999 to 2009. Vector plots of the 5 benthic taxa variables used in the Principal Coordinate Analysis are overlaid $(\mathrm{S}=$ stony corals, $\mathrm{O}=$ octocorals, $\mathrm{M}=$ macroalgae, $\mathrm{P}=$ sponge and $\mathrm{Z}=$ zoanthids). Multiple partial correlation values used to produce the vector plots are given in Table 3. The circle scales correlation values to an absolute value of 1 
mortality of $O$. annularis, it is also apparent that other factors (e.g. disease and predation), in addition to thermal stress, have placed this species in a perpetual state of decline (Fig. 3). As stony corals have failed to recover, octocorals have become an increasingly large component of the benthic fauna. Octocorals were also negatively affected during the 1997/ 1998 El Niño (Fig. 2), but demonstrated greater resilience than other benthic fauna in the Florida Keys after 1999. An overall trend of increasing cover was reported for octocorals Keys-wide and across all reef types (Table 1), resulting in a shift in community structure at the deep and shallow forereefs (Fig. 4). Although this transition is apparent Keys-wide, its progression has varied across habitats because of differences in community structure and the discordant timing of disturbances that led to stony coral decline.

Nowhere is the transition to octocorals more noticeable in the Florida Keys than on the shallow forereefs. During this study, octocoral cover significantly increased at 9 of the 12 shallow forereefs (Table 2) and overwhelmingly explained the directional shift in community structure (Fig. 4A). Acropora palmata and A. cervicornis, at one time the predominant corals in this habitat, have undergone a long period of decline dating to the 1960s (Aronson \& Precht 2001). Extant stands of these corals in the Florida Keys are now estimated to be $<1 \%$ of their original size as a result of disease, hurricanes and thermal stress (Dustan \& Halas 1987, Porter \& Meier 1992, Miller et al. 2002, Patterson et al. 2002, Precht \& Miller 2006). The few remaining stands of $A$. palmata have continued to decline (Porter et al. 2012, Williams \& Miller 2012), and Allee effects now pose significant barriers to recovery of the small, remnant population in the Florida Keys (Vollmer \& Kline 2008, Williams et al. 2008, Porter et al. 2012). Irrespective of acroporids, total stony coral cover continued to decline on shallow forereefs between 1999 and 2009 (Table 1). Even though the decline was not specifically attributed to trends of any of the 5 predominant coral species, it appears that conditions on shallow reefs are not conducive to the recovery of acroporids or the broader stony coral community.

At deep forereefs, the change in community structure was less pronounced. This is partly due to octocoral cover already exceeding total stony coral cover at project inception, but also because the greater abundance of macroalgae on deep forereefs obscured the transition. Macroalgal cover did not significantly change on deep forereefs between 1999 and 2009 (Table 1), but interannual fluctuations in macroalgae influenced community composition more than the changes in octocoral and sponge cover (Fig. 4B). The growing disparity between octocoral and stony coral cover at deep forereefs also progressed more slowly because it was associated with the demise of Orbicella annularis. Unlike diseases that vacated large stands of acroporids from shallow forereefs 30 to 40 yr ago (Dustan \& Halas 1987, Aronson \& Precht 2001), epizootics and mass bleaching events affecting $O$. annularis have arisen more recently (Goreau et al. 1998, Porter et al. 2001). These conditions often result in partial mortality that slowly kills the colony over many years (Aronson \& Precht 2006, Edmunds \& Elahi 2007). Recurring incidences of partial mortality on large colonies likely led to the decline of $O$. annularis on deep forereefs between 1999 and 2009 (Fig. 3C), a pattern consistent with descriptions provided from other Caribbean localities (Edmunds \& Elahi 2007, Bruckner 2012). Prolonged recruitment failure has limited its recovery (Hughes \& Tanner 2000, Miller et al. 2000), and if the gradual demise of $O$. annularis continues, it will further facilitate the transition to other benthic fauna on deep forereefs.

The changes unfolding at forereefs likely foreshadow patterns that will emerge on patch reefs in upcoming years. Situated inshore of forereefs, patch reefs are subjected to greater fluctuations in water temperature, salinity, and turbidity than offshore forereefs, where these parameters are regulated more by oceanic currents (Ginsburg \& Shinn 1964, Ginsburg \& Shinn 1994). This chronic exposure to environmental extremes is hypothesized to have resulted in benthic assemblages that are more resilient to disturbances than those on forereefs (Lirman \& Fong 2007, Soto et al. 2011). Scleractinian mortality was less severe on patch reefs than on forereefs during the 1997/1998 El Niño, and patch reefs were the only habitat in this study that did not experience a decline in stony coral cover between 1999 and 2009 (Table 1). However, in 2010, a record breaking winter in the Florida Keys depressed nearshore water temperatures well below the lethal threshold for many tropical taxa and caused catastrophic mortality (Kemp et al. 2011, Lirman et al. 2011, Colella et al. 2012). The entire benthic assemblage (e.g. stony corals, octocorals, sponges) was affected, but Orbicella annularis was particularly susceptible to coldwater stress, with large stands nearly extirpated on reefs that endured the longest exposure (Kemp et al. 2011, Colella et al. 2012). Prior to this cold-water mortality, community structure on patch reefs had remained similar (Fig. 4C). Considering that octocoral cover was already the largest constituent in 1999 
and significantly increased through 2009, it is likely that octocorals will emerge as the predominant taxa on patch reefs following the cold-water disturbance.

The transition from stony coral- to octocoraldominated communities has been reported before; however, all examples are exclusive to the Pacific (Fox et al. 2003, Stobart et al. 2005). Our results provide quantitative evidence that octocorals are emerging as the most abundant taxa in the present-day Florida Keys, but qualitative information suggests that this transition may have started during the last century and accelerated after widespread mortality of stony corals. Early maps from the Dry Tortugas indicate that octocorals inhabited $\sim 5 \%$ of the available hardbottom in 1881 (Agassiz 1883). When the same area was mapped nearly 100 yr later, octocoral communities had expanded more than 3-fold, covering $\sim 17 \%$ of the habitat (Davis 1982). Anecdotal evidence of octocorals emerging on the shallow forereefs is also supplied by a $50 \mathrm{yr}$ photographic time series from Grecian Rocks, an extensively studied reef in the upper Florida Keys (Shinn 1980, 2012). After Acropora cervicornis thickets were decimated by hurricanes, disease, and other stressors, octocorals were effective at colonizing the rubble left behind. Although this transition started decades ago, it is still underway, as Grecian Rocks was 1 of the 9 shallow forereefs for which a trend of increasing octocoral cover was identified in this study. The geological record provides evidence that octocorals have been an important component of the Florida Reef Tract during the latter Holocene (Lighty et al. 1978), and a few earlier studies noted that octocoral density and species richness could exceed that of stony corals on some reefs in the Keys (Wheaton \& Jaap 1988, Chiappone \& Sullivan 1997). Thus, while some of the current transition has been aided by stochastic events, it may coincide with sustained, longer-term environmental changes that are having protracted effects on community structure.

Octocoral values reported here represent a combination of both canopy (branching species) and benthic (encrusting species) cover. One caveat regarding the identification of octocorals in CREMP's image analysis is that canopy cover can expand without additional colonization of substrate or recruitment of new colonies. Nonetheless, the sole use of percent cover does not detract from our findings because octocoral cover rebounded twice after major periods of disturbance in the Florida Keys. Our findings suggest that the increase in cover after these disturbances was achieved more by a population increase than by growth of the existing canopy. The most recent decline in octocoral cover occurred after the 2004 and 2005 hurricane seasons. Hurricanes detach octocoral holdfasts from the substrate, often resulting in complete mortality of the colony (Woodley et al. 1981, Yoshioka \& Yoshioka 1991). Therefore, the increase in cover observed after 2006 was likely achieved by the settlement of new recruits rather than regeneration of surviving colonies (Fig. 2). Similarly, during the 1997/1998 El Niño, diseases and tissue sloughing resulted in substantial mortality to octocorals (Cerrano et al. 2000, Harvell et al. 2001, Lasker 2005). Large sections of the reef were left barren after this disturbance and a comparison of panoramic images extracted from our video, taken in 2001 and 2009, verified the establishment of new octocorals in depauperate areas (Fig. 5).

Substantial evidence indicates that when Caribbean reefs undergo extensive stony coral mortality, they will enter into a macroalgal-dominated state (Bellwood et al. 2004, McManus \& Polsenberg 2004, Aronson \& Precht 2006, Rogers \& Miller 2006, Bruno et al. 2009, Roff \& Mumby 2012). This transition has been ascribed to the Florida Keys before (Pandolfi et al. 2005, Maliao et al. 2008), but these studies came to this conclusion using shorter time series (e.g. $<5 \mathrm{yr}$ in Maliao et al. 2008). An ephemeral spike in macroalgal cover immediately following the 1997/1998 El Niño may have warranted this summation, but macroalgal values thereafter returned to levels similar to those observed in 1996 (Fig. 2). Trends of increasing macroalgal cover were observed at some sites (Table 2), but these instances were isolated and did not reflect patterns at larger spatial scales (e.g. habitat or Keys-wide). Macroalgae was an influential biotic component in all habitats (Fig. 4), but varied spatially and temporally in this study (Fig. 2). Understanding the proximate causes of macroalgal growth in the Florida Keys is complex and has long been a subject of contentious debate (Precht \& Miller 2006). Regional factors such as upwelling (Leichter et al. 2003), the deposition and transport of nutrients throughout the Caribbean basin (Shinn et al. 2000), and scouring by hurricanes and winter storms may be as equally influential as localized sources in regulating the distribution and abundance of macroalgae in the Florida Keys. Since 1996, the greatest abundance of macroalgae in the Florida Keys has been consistently found on the deep forereefs, which are the greatest distance from shore (Fig. 2). While annual macroalgal cover values reported here are higher than historical baselines for Caribbean reefs (Côté et al. 2005, Paddack et al. 2006), it was not responsible for any directional shifts in community 

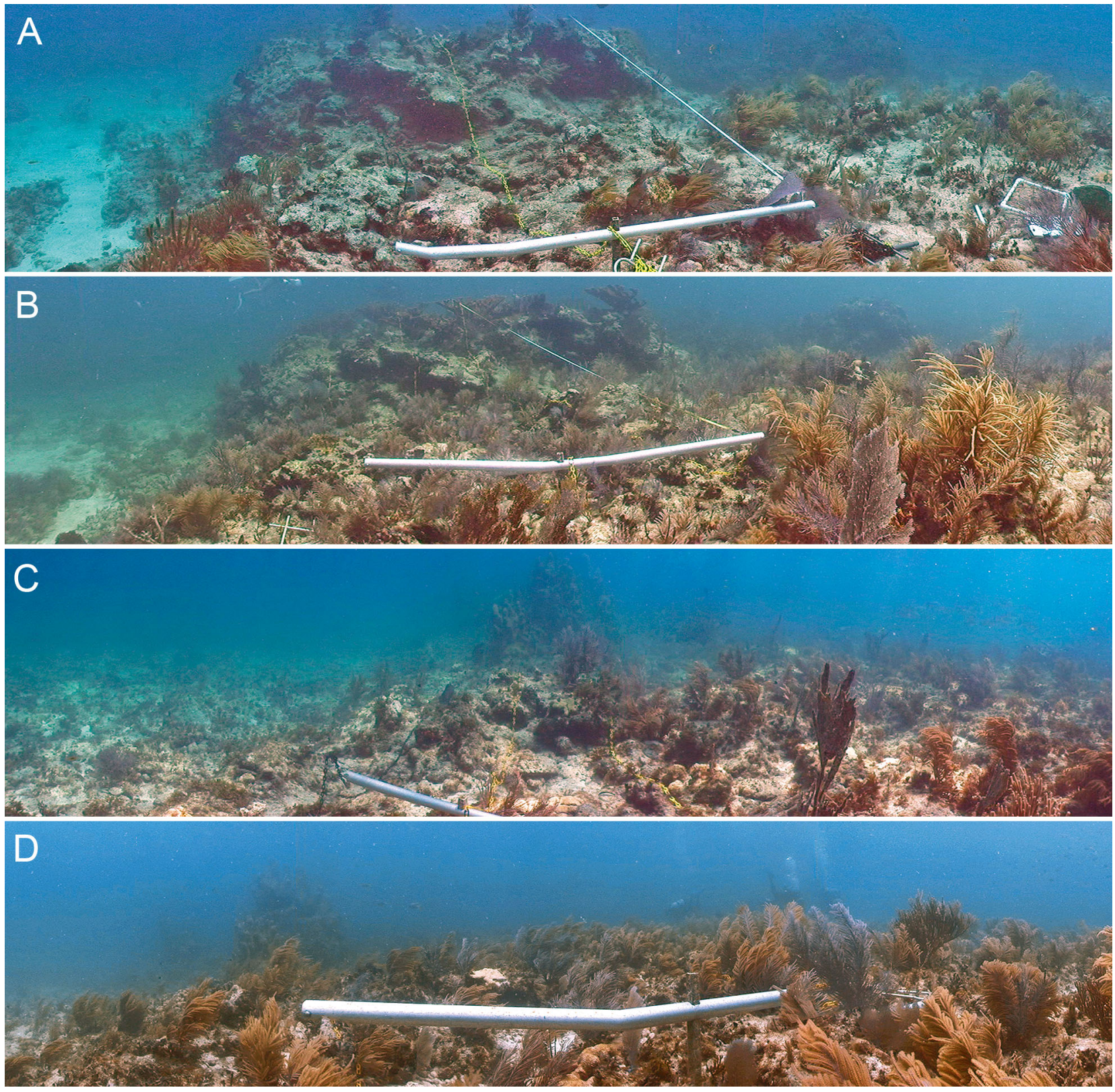

Fig. 5. Panoramic images extracted from video, filmed in 2001 and 2009 at 2 shallow forereefs in the Florida Keys: (A) Molasses 2001 (B) Molasses 2009 (C) Conch 2001 (D) Conch 2009

structure following the 1997/1998 El Niño (Fig. 4), which suggests that Florida Keys reefs did not sustain a further increase in macroalgae.

The concern that many of the world's reefs are being overtaken by macroalgae has led resource managers to focus primarily on conserving herbivores and improving water quality (Szmant 2002, Bellwood et al. 2004, Aronson \& Precht 2006, Hughes et al. 2007, Bruno et al. 2009). Management strategies aimed at achieving these goals have been implemented in the Florida Keys. The US Environmental
Protection Agency's Water Quality Protection Program, in partnership with the Florida Keys National Marine Sanctuary (FKNMS), has invested millions of dollars into advanced wastewater treatment, in efforts to restore water quality and prevent the entry of partially treated sewage into the watershed (Kruczynski 2005, Kruczynski \& McManus 1999). Federal and State fisheries regulations prohibit the harvest of herbivorous fishes (e.g. parrotfishes and surgeonfishes) for commercial consumption and ban indiscriminate fishing techniques such as fish traps (Aron- 
son \& Precht 2006, FFWCC 2013). The removal of herbivorous fishes, coupled with the loss of Diadema antillarum, has led to dramatic increases in macroalgal cover on other Caribbean reefs (Jackson et al. 2001, K. G. Porter et al. 2002, Rogers \& Miller 2006). Indeed, macroalgal values reported in this study are lower than those reported for other Caribbean reefs (Schutte et al. 2010). Considering the population of $D$. antillarum in the Florida Keys is still well below historical levels following its mass mortality in the 1980s (Chiappone et al. 2002), the protection of herbivorous fishes may have helped avert a sustained increase in macroalgae following the 1997/1998 El Niño. However, while these management actions merit recognition, macroalgal cover did not decrease at larger spatial scales during this study (Table 1). Thus, current management efforts in the Florida Keys may be effective at preventing additional macroalgal expansion, but there is less evidence they can reduce the overall biomass to historical baselines (Paddack et al. 2006).

Two studies have reported an increase in sponges in the Florida Keys (Ward-Paige et al. 2005, McMurray et al. 2010), but both studies centered on a single species (Xestospongia muta) or a single genus (Cliona) of sponge. In the case of clionaid sponges, a Keys-wide increase in sponge abundance and cover was documented from 1996 through 2001 (Ward-Paige et al. 2005). McMurray et al. (2010) documented an increase in $X$. muta abundance between 2000 and 2006, but their study was limited to 2 reefs. The distribution of $X$. muta is restricted to deeper reefs in the Florida Keys and Caribbean (Schmahl 1990, Zea 1993), which may correspond with the trend of increasing sponge cover observed on the deep forereefs in this study. While our results appear to corroborate their findings, further evaluation is needed to determine whether other sponge species are contributing to the increase in sponge cover on deep forereefs or if $X$. muta is solely responsible. Phase shifts in which sponges have become the predominant taxa have been described for other Caribbean localities, but they have been achieved by small or encrusting morphotypes (Aronson et al. 2002, Rutzler 2002, Weil et al. 2002) rather than large, slow-growing species like $X$. muta (McMurray et al. 2008). Regardless, even if $X$. muta populations are expanding on the deep forereefs, the increase in cover has had little influence on the overall benthic assemblage in this habitat and illustrates why increases in a single benthic component do not necessarily correlate with shifts in community composition (Fig. 4C). Likewise, if clionaid abundance and cover has increased in some localities, it has not translated to an overall increase in sponge cover Keys-wide or on shallow forereefs and patch reefs.

How the transition to octocorals will impact benthic communities on Florida Keys reefs will require further study. While the exact mechanisms (e.g. reproductive output, recruitment success, juvenile survivorship) are unclear, octocorals have demonstrated a greater capacity than other benthic fauna to recover after disturbances in the Florida Keys. The establishment of positive feedback mechanisms may allow octocorals to retain their increased presence while negating the recovery of stony corals. Octocorals are direct spatial competitors with stony corals and can reduce settlement through allelopathic interactions and predation (Maida et al. 1995, 2001). Octocorals may also be more resistant to threats posed by global climate change. Temperature-induced stress can lead to direct necrosis of octocorals in extreme cases (Cerrano et al. 2000, Lasker 2005, Colella et al. 2012), but warm-water anomalies do not elicit the same mass bleaching response in octocorals as that observed in stony corals (Prada et al. 2010). Only a few species of octocorals are known to bleach, and their symbiont organization may make them less prone to bleaching than stony corals (Lasker et al. 1984, Goulet \& Coffroth 2004). Likewise, the effect of ocean acidification may be less pronounced on octocorals than stony corals because their skeletons are constructed primarily of protein; calcium carbonate is only retained in their sclerites (Bayer 1961). Octocorals support diverse and abundant fish assemblages, offer habitat and shelter, and are consumed by a variety of predators (Wolff et al. 1999, Gratwicke et al. 2006). However, reef accretion, topographic complexity, and rugosity will be altered when stony corals are not the principal constituent (Alvarez-Filip et al. 2009), which could lead to changes in the behavior, distribution, and abundance of commensal organisms (Precht et al. 2010).

The results presented here provide a mixed outlook for the Florida Keys. Despite cover for 4 of the 5 most prevalent corals remaining unchanged during the 11 yr study period, the demise of Orbicella annularis led to a continued loss of stony coral cover at deep and shallow forereefs. While eurytopic scleractinian species will continue to constitute some portion of the benthic assemblage, octocorals and sponges will form a greater part of the reef community. Octocorals appear more resilient to disturbances than do stony corals, and the conditions triggering their emergence in the Florida Keys may have started long ago. In some cases, phase shifts from 
stony coral- to macroalgal-dominated communities have been reversed after corrective actions were implemented or populations of herbivores were restored (Edmunds \& Carpenter 2001, Idjadi et al. 2006, Mumby et al. 2007), but there is less evidence of this reversal when benthic taxa other than macroalgae become the predominant benthic constituent (Norström et al. 2009). Given that the threats to stony corals associated with global climate change (e.g. decreased calcification, increased disease virulence, and bleaching) are projected to increase (Harvell et al. 2004, Hoegh-Guldberg et al. 2007, Baker et al. 2008), and considering that current environmental conditions and management actions have not fostered stony coral regeneration, we postulate that the benthic community trends reported here predict how Florida Keys reefs will be structured into the near future.

Acknowledgements. Long-term monitoring programs like CREMP are indebted to a long list of people who have contributed to the work over the years. Special recognition is reserved for several of the program's founders, including W. Jaap, J. Wheaton, Dr. P. Dustan, F. McManus, and B. Kruczynski, whose perseverance and dedication helped make CREMP a world-renowned program. Funding to support the program has been principally achieved through the US EPA Water Quality Protection Program (X7-97468002), but additional support was provided by the State of Florida Marine Resource Conservation Trust Fund and grants from the National Oceanic and Atmospheric Administration and the US Army Corps of Engineers (MOA-2001-683), as well as the National Science Foundation (NSF-1015342). We are grateful to Dr. E. Leone, Dr. M. Christman, and Dr. D. Jones, whose technical expertise and guidance greatly aided the univariate modeling and multivariate analyses performed in this study. The recommendations of 3 anonymous reviewers improved the quality of this manuscript. The statements, conclusions, and recommendations expressed herein are those of the authors and do not necessarily reflect the views of the State of Florida, the Environmental Protection Agency, or the Florida Keys National Marine Sanctuary.

\section{LITERATURE CITED}

Agassiz A (1883) Explorations of the surface fauna of the Gulf Stream, under the auspices of the United States Coast Survey. II. The Tortugas and Florida Reefs. Mem Am Acad Arts Sci Centennial Vol II:107-132

> Alvarez-Filip L, Dulvy NK, Gill JA, Côté IM, Watkinson AR (2009) Flattening of Caribbean coral reefs: region-wide declines in architectural complexity. Proc R Soc Lond B Biol Sci 276:3019-3025

Aronson RB, Precht WF (1997) Stasis, biological disturbance, and community structure of a Holocene coral reef. Paleobiology 23:326-346

Aronson RB, Precht WF (2001) White-band disease and the changing face of Caribbean coral reefs. Hydrobiologia 460:25-38

Aronson RB, Precht WF (2006) Conservation, precaution and
Caribbean reefs. Coral Reefs 25:441-450

Aronson R, Precht W, Toscano M, Koltes K (2002) The 1998 bleaching event and its aftermath on a coral reef in Belize. Mar Biol 141:435-447

> Aronson RB, Macintyre IG, Wapnick CM, O'Neill MW (2004) Phase shifts, alternative states, and the unprecedented convergence of two reef systems. Ecology 85: 1876-1891

> Baker AC, Glynn PW, Riegl B (2008) Climate change and coral reef bleaching: an ecological assessment of longterm impacts, recovery trends and future outlook. Estuar Coast Shelf Sci 80:435-471

Bayer FM (1961) The shallow-water octocorallia of the West Indian Region, Vol XII. Smithsonian Institution, Washington, DC

Bellwood DR, Hughes TP, Folke C, Nystroem M (2004) Confronting the coral reef crisis. Nature 429:827-833

Bruckner A (2012) Factors contributing to the regional decline of Montastraea annularis (complex) In: Yellowlees D, Hughes TP (eds) Proc 12th Int Coral Reef Symp, Cairns, Australia, 9-13 Jul 2012, http://www.icrs 2012.com/proceedings/manuscripts/ICRS2012_11B_1.pdf

> Bruno JF, Selig ER, Casey KS, Page CA and others (2007) Thermal stress and coral cover as drivers of coral disease outbreaks. PLoS Biol 5:e124

> Bruno JF, Sweatman H, Precht WF, Selig ER, Schutte VGW (2009) Assessing evidence of phase shifts from coral to macroalgal dominance on coral reefs. Ecology 90: 1478-1484

Budd AF, Fukami H, Smith ND, Knowlton N (2012) Taxonomic classification of the reef coral family Mussidae (Cnidaria: Anthozoa: Scleractinia). Zool J Linn Soc 166: 465-529

Burke L, Reytar K, Spalding M, Perry A (2011) Reef at risk revisited. World Resources Institute, Washington, DC

Burnham KP, Anderson DR (2002) Model selection and multimodel inference: a practical information-theoretic approach Vol 2. Springer-Verlag, New York, NY

Causey B (2001) Lessons learned from the intensification of coral bleaching from 1980-2000 in the Florida Keys, USA. In: Salm RV, Coles SL (eds) Coral bleaching and marine protected areas: Proc workshop mitigating coral bleaching impact through MPA design. Asia Pacific Coastal Marine Program Report \#0102, p 60-66

> Cerrano C, Bavestrello G, Bianchi CN, Cattaneo-vietti R and others (2000) A catastrophic mass-mortality episode of gorgonians and other organisms in the Ligurian Sea (north-western Mediterranean), summer 1999. Ecol Lett 3:284-293

Chiappone M, Sullivan JR (1997) Rapid assessment of reefs in the Florida Keys: results from a synoptic survey. In: Lessios HA, Macintyre IG (eds) Proc 8th Int Coral Reef Symp 2:1509-1514

Chiappone M, Swanson DW, Miller SL (2002) Density, spatial distribution and size structure of sea urchins in Florida Keys coral reef and hard-bottom habitats. Mar Ecol Prog Ser 235:117-126

Clarke KR, Gorley RN (2006) PRIMER v6: user manual/tutorial. PRIMER-E, Plymouth

Colella M, Ruzicka R, Kidney J, Morrison J, Brinkhuis V (2012) Cold-water event of January 2010 results in catastrophic benthic mortality on patch reefs in the Florida Keys. Coral Reefs 31:621-632

Connell JH (1997) Disturbance and recovery of coral assemblages. Coral Reefs 16:S101-S113 
Connell JH, Slatyer RO (1977) Mechanisms of succession in natural communities and their role in community stability and organization. Am Nat 111:1119-1144

Côté IM, Gill JA, Gardner TA, Watkinson AR (2005) Measuring coral reef decline through meta-analyses. Philos Trans R Soc Lond B Biol Sci 360:385-395

Davis GE (1982) A century of natural change in coral distribution at the Dry Tortugas: a comparison of reef maps from 1881 and 1976. Bull Mar Sci 32:608-623

$>$ De'ath G, Fabricius KE, Sweatman H, Puotinen M (2012) The 27-year decline of coral cover on the Great Barrier Reef and its causes. Proc Natl Acad Sci USA 109: 17995-17999

> Diaz-Pulido G, McCook LJ, Dove S, Berkelmans R and others (2009) Doom and boom on a resilient reef: climate change, algal overgrowth and coral recovery. PLoS ONE 4:e5239

Done TJ (1992) Phase shifts in coral reef communities and their ecological significance. Hydrobiologia 247:121-132

> Dudgeon SR, Aronson RB, Bruno JF, Precht WF (2010) Phase shifts and stable states on coral reefs. Mar Ecol Prog Ser 413:201-216

> Dustan P, Halas JC (1987) Changes in the reef-coral community of Carysfort Reef, Key Largo, Florida: 1974 to 1982. Coral Reefs 6:91-106

Edmunds PJ, Carpenter RC (2001) Recovery of Diadema antillarum reduces macroalgal cover and increases abundance of juvenile corals on a Caribbean reef. Proc Natl Acad Sci USA 98:5067-5071

Edmunds PJ, Elahi R (2007) The demographics of a 15-year decline in cover of the Caribbean reef coral Montastraea annularis. Ecol Monogr 77:3-18

FFWCC (2013) Florida Fish and Wildlife Conservation Commission. Marine fisheries. Gear specifications and prohibited gear. Available at https://www.flrules.org/Gateway/View_notice.asp?id=2603206. (accessed 2 Feb 2013)

> Fox HE, Pet JS, Dahuri R, Caldwell RL (2003) Recovery in rubble fields: long-term impacts of blast fishing. Mar Pollut Bull 46:1024-1031

Gardner TA, Cote IM, Gill JA, Grant A, Watkinson AR (2003) Long-term region-wide declines in Caribbean corals. Science 301:958-960

Ginsburg RN, Shinn EA (1964) Distribution of the reefbuilding community in Florida and the Bahamas. Am Assoc Pet Geol Bull 48:527

Ginsburg RN, Shinn EA (1994) Preferential distribution of reefs in the Florida Reef Tract: the past is the key to the present In: Ginsburg RN (ed) Proc colloquium on global aspects of coral reefs: health hazards and history. Rosenstiel School of Marine and Atmospheric Science, University of Miami, FL, p 21-26

Glynn PW, Colley SB (eds) (2001) A collection of studies on the effects of the 1997-98 El Niño-Southern Oscillation event on corals and coral reefs in the eastern tropical Pacific. Bull Mar Sci 69:1-288

Goreau TJ, Cervino JM, Goreau M, Hayes R and others (1998) Rapid spread of diseases in Caribbean coral reefs. Rev Biol Trop 46(Suppl 5):157-171

Goulet T, Coffroth M (2004) The genetic identity of dinoflagellate symbionts in Caribbean octocorals. Coral Reefs 23:465-472

Gratwicke B, Petrovic C, Speight MR (2006) Fish distribution and ontogenetic habitat preferences in nonestuarine lagoons and adjacent reefs. Environ Biol Fishes 76:191-210
Green DH, Edmunds PJ, Carpenter RC (2008) Increasing relative abundance of Porites astreoides on Caribbean reefs mediated by an overall decline in coral cover. Mar Ecol Prog Ser 359:1-10

- Harvell CD, Kim K, Burkholder JM, Colwell RR and others (1999) Emerging marine diseases-climate links and anthropogenic factors. Science 285:1505-1510

Harvell D, Kim K, Quirolo C, Weir J, Smith G (2001) Coral bleaching and disease: contributors to 1998 mass mortality in Briareum asbestinum (Octocorallia, Gorgonacea). Hydrobiologia 460:97-104

> Harvell D, Aronson R, Baron N, Connell J and others (2004) The rising tide of ocean diseases: unsolved problems and research priorities. Front Ecol Environ 2:375-382

- Hoegh-Guldberg O, Mumby PJ, Hooten AJ, Steneck RS and others (2007) Coral reefs under rapid climate change and ocean acidification. Science 318:1737-1742

Hughes TP (1994) Catastrophes, phase shifts, and largescale degradation of a Caribbean coral reef. Science 265: 1547-1551

Hughes TP, Tanner JE (2000) Recruitment failure, life histories, and long-term decline of Caribbean corals. Ecology 81:2250-2263

Hughes TP, Baird AH, Bellwood DR, Card M and others (2003) Climate change, human impacts, and the resilience of coral reefs. Science 301:929-933

> Hughes TP, Bellwood DR, Folke CS, McCook LJ, Pandolfi JM (2007) No-take areas, herbivory and coral reef resilience. Trends Ecol Evol 22:1-3

Idjadi J, Lee S, Bruno J, Precht W, Allen-Requa L, Edmunds P (2006) Rapid phase-shift reversal on a Jamaican coral reef. Coral Reefs 25:209-211

> Jackson JBC, Kirby MX, Berger WH, Bjorndal KA and others (2001) Historical overfishing and the recent collapse of coastal ecosystems. Science 293:629-637

Johns GM, Leeworthy VR, Bell FW, Bonn MA (2001) Socioeconomic study of reefs in southeast Florida-final report. Hazen and Sawyer Environmental Engineers \& Scientists, Hollywood, FL

Kemp DW, Oakley CA, Thornhill DJ, Newcomb LA, Schmidt GW, Fitt WK (2011) Catastrophic mortality on inshore coral reefs of the Florida Keys due to severe low-temperature stress. Glob Change Biol 17:3468-3477

Kruczynski WL (2005) Response to 'Are US coral reefs on the slippery slope to slime?' Science 308:1741

Kruczynski WL, McManus F (1999) Water quality concerns in the Florida Keys: sources, effects, and solutions. In: Porter JW, Porter KG (eds) The Everglades, Florida Bay, and coral reefs in the Florida Keys: an ecosystem sourcebook. CRC Press, Boca Raton, FL, p 827-881

- Lapointe BE, Matzie WR (1996) Effects of stormwater nutrient discharges on eutrophication processes in nearshore waters of the Florida Keys. Estuar Coast 19:422-435

Lasker HR (2005) Gorgonian mortality during a thermal event in the Bahamas. Bull Mar Sci 76:155-162

> Lasker H, Peters E, Coffroth M (1984) Bleaching of reef coelenterates in the San Blas Islands, Panama. Coral Reefs 3:183-190

Leichter JJ, Stewart HL, Miller SL (2003) Episodic nutrient transport to Florida coral reefs. Limnol Oceanogr 48: 1394-1407

Lessios HA, Robertson DR, Cubit JD (1984) Spread of Diadema mass mortality through the Caribbean. Science 226:335-337

> Lighty RG, Macintyre IG, Stuckenrath R (1978) Submerged 
early Holocene barrier reef south-east Florida shelf. Nature 276:59-60

Lipp EK, Jarrell JL, Griffin DW, Lukasik J, Jacukiewicz J, Rose JB (2002) Preliminary evidence for human fecal contamination in corals of the Florida Keys, USA. Mar Pollut Bull 44:666-670

$>$ Lirman D, Fong P (2007) Is proximity to land-based sources of coral stressors an appropriate measure of risk to coral reefs? An example from the Florida Reef Tract. Mar Pollut Bull 54:779-791

Lirman D, Schopmeyer S, Manzello D, Gramer LJ and others (2011) Severe 2010 cold-water event caused unprecedented mortality to corals of the Florida Reef Tract and reversed previous survivorship patterns. PLoS ONE 6: e23047

Maida M, Sammarco PW, Coll JC (1995) Effects of soft corals on scleractinian coral recruitment. I: Directional allelopathy and inhibition of settlement. Mar Ecol Prog Ser 121: 191-202

Maida M, Sammarco PW, Coll JC (2001) Effects of soft corals on scleractinian coral recruitment. II: Allelopathy, spat survivorship and reef community structure. PSZNI: Mar Ecol 22:397-414

Maliao R, Turingan R, Lin J (2008) Phase-shift in coral reef communities in the Florida Keys National Marine Sanctuary (FKNMS), USA. Mar Biol 154:841-853

McClenachan L (2009) Documenting loss of large trophy fish from the Florida Keys with historical photographs. Conserv Biol 23:636-643

McManus JW, Polsenberg JF (2004) Coral-algal phase shifts on coral reefs: ecological and environmental aspects. Prog Oceanogr 60:263-279

McMurray SE, Blum JE, Pawlik JR (2008) Redwood of the reef: growth and age of the giant barrel sponge Xestospongia muta in the Florida Keys. Mar Biol 155: 159-171

McMurray SE, Henkel TP, Pawlik JR (2010) Demographics of increasing populations of the giant barrel sponge Xestospongia muta in the Florida Keys. Ecology 91: 560-570

> Miller MW, Weil E, Szmant AM (2000) Coral recruitment and juvenile mortality as structuring factors for reef benthic communities in Biscayne National Park, USA. Coral Reefs 19:115-123

Miller MW, Bourque AS, Bohnsack JA (2002) An analysis of the loss of acroporid corals at Looe Key, Florida, USA: 1983-2000. Coral Reefs 21:179-182

> Mumby PJ, Harborne AR, Williams J, Kappel CV and others (2007) Trophic cascade facilitates coral recruitment in a marine reserve. Proc Natl Acad Sci USA 104:8362-8367

> Norström AV, Nyström M, Lokrantz J, Folke C (2009) Alternative states on coral reefs: beyond coral-macroalgal phase shifts. Mar Ecol Prog Ser 376:295-306

Osborne K, Dolman AM, Burgess SC, Johns KA (2011) Disturbance and the dynamics of coral cover on the Great Barrier Reef (1995-2009). PLoS ONE 6:e17516

Paddack MJ, Cowen RK, Sponaugle S (2006) Grazing pressure of herbivorous coral reef fishes on low coral-cover reefs. Coral Reefs 25:461-472

Pandolfi JM, Bradbury RH, Sala E, Hughes TP and others (2003) Global trajectories of the long-term decline of coral reef ecosystems. Science 301:955-958

Pandolfi JM, Jackson JBC, Baron N, Bradbury RH and others (2005) Are US coral reefs on the slippery slope to slime? Science 307:1725-1726
Patterson KL, Porter JW, Ritchie KB, Polson SW and others (2002) The etiology of white pox, a lethal disease of the Caribbean elkhorn coral, Acropora palmata. Proc Natl Acad Sci USA 99:8725-8730

> Pawlik JR (2011) The chemical ecology of sponges on Caribbean reefs: natural products shape natural systems. BioScience 61:888-898

Petraitis PS, Dudgeon SR (2004) Detection of alternative stable states in marine communities. J Exp Mar Biol Ecol 300:343-371

Porter JW, Meier OW (1992) Quantification of loss and change in Floridian reef coral populations. Am Zool 32: 625-640

Porter JW, Dustan P, Jaap WC, Patterson KL and others (2001) Patterns of spread of coral disease in the Florida Keys. Hydrobiologia 460:1-3

Porter JW, Kosmynin V, Patterson KL, Porter KG and others (2002) Detection of coral reef change by the Florida Keys Coral Reef Monitoring Project. In: Porter JW, Porter KG (eds) The Everglades, Florida Bay, and coral reefs of the Florida Keys: an ecosystem sourcebook. CRC Press, Boca Raton, FL, p 749-770

Porter JW, Meyers MK, Ruzicka RR, Callahan MK and others (2012) Catastrophic loss of Acropora palmata in the Florida Keys: Failure of the 'Sorcerer's Apprentice Effect' to aid recovery following the 2005 Atlantic hurricane season. In: Yellowlees D, Hughes TP (eds) Proc 12th Int Coral Reef Symp, Cairns, Australia, 9-13 Jul 2012, http:// www.icrs2012.com/proceedings/manuscripts/ICRS2012 _19B_1.pdf

Porter KG, Porter JW, Porter DW, Thacker K and others (2002) Patterns of coral reef development in the Negril Marine Park: necessity for a whole-watershed management plan. In: Porter JW, Porter KG (eds) The Everglades, Florida Bay, and coral reefs of the Florida Keys: an ecosystem source book. CRC Press, Boca Raton, FL, p 917-938

> Prada C, Weil E, Yoshioka PM (2010) Octocoral bleaching during unusual thermal stress. Coral Reefs 29:41-45

Precht WF, Miller SL (2006) Ecological shifts along the Florida Reef Tract: the past as a key to the future. In: Aronson RB (ed) Geological approaches to coral reef ecology. Springer, New York, NY, p 237-312

Precht WF, Aronson RB, Moody RM, Kaufman L (2010) Changing patterns of microhabitat utilization by the threespot damselfish, Stegastes planifrons, on Caribbean reefs. PLoS ONE 5:e10835

Roff G, Mumby PJ (2012) Global disparity in the resilience of coral reefs. Trends Ecol Evol 27:404-413

> Rogers CS, Miller J (2006) Permanent 'phase shifts' or reversible declines in coral reef cover? Lack of recovery of two reefs in St. John, US Virgin Islands. Mar Ecol Prog Ser 306:103-114

Rutzler K (2002) Impact of crustose clionid sponges on Caribbean reef corals. Acta Geol Hisp 37:61-72

Ruzicka R, Semon K, Colella MA, Brinkhuis V and others (2010) CREMP 2009 final report. Fish \& Wildlife Research Institute, Florida, Fish \& Wildlife Conservation Commission, Saint Petersburg, FL

Schmahl GP (1990) Community structure and ecology of sponges associated with four southern Florida coral reefs. In: Rutzler K (ed) New perspectives in sponge biology. Smithsonian Institute Press, Washington, DC, p 376-383

> Schutte VGW, Selig ER, Bruno JF (2010) Regional spatio- 
temporal trends in Caribbean coral reef benthic communities. Mar Ecol Prog Ser 402:115-122

Shinn EA (1980) Geologic history of Grecian Rocks, Key Largo coral reef marine sanctuary. Bull Mar Sci 30: 646-656

Shinn EA (2012) Fifty years of coral boom and bust at Grecian Rocks Reef. In: Kruczynski WL, Fletcher PJ (eds) Tropical connections: south Florida's marine environment. IAN Press, University of Maryland Center for Environmental Science, Cambridge, MD, p 219

Shinn EA, Smith GW, Prospero JM, Betzer P, Hayes ML, Garrison V, Barber RT (2000) African dust and the demise of Caribbean coral reefs. Geophys Res Lett 27: 3029-3032

Somerfield PJ, Jaap WC, Clarke KR, Callahan M and others (2008) Changes in coral reef communities among the Florida Keys, 1996-2003. Coral Reefs 27:951-965

Soto IM, Muller Karger FE, Hallock P, Hu C (2011) Sea surface temperature variability in the Florida Keys and its relationship to coral cover. J Mar Biol 2011:981723, doi: 10.1155/2011/981723

Steneck RS (1988) Herbivory on coral reefs: a synthesis. In: Choat JH, Barnes D, Borowitzka MA, Coll JC and others (eds) Proc 6th Int Coral Reef Symp, Townsville, p 37-49

Stobart B, Teleki K, Buckley R, Downing N, Callow M (2005) Coral recovery at Aldabra Atoll, Seychelles: five years after the 1998 bleaching event. Philos Trans R Soc Lond A 363:251-255

Sweatman H, Delean S, Syms C (2011) Assessing loss of coral cover on Australia's Great Barrier Reef over two decades, with implications for longer-term trends. Coral Reefs 30:521-531

Szmant A (2002) Nutrient enrichment on coral reefs: is it a major cause of coral reef decline? Estuaries 25: 743-766

Vollmer SV, Kline DI (2008) Natural disease resistance in

Editorial responsibility: Peter Edmunds,

Northridge, California, USA threatened staghorn corals. PLoS ONE 3:e3718

- Wagner DE, Kramer P, van Woesik R (2010) Species composition, habitat, and water quality influence coral bleaching in southern Florida. Mar Ecol Prog Ser 408:65-78

- Ward-Paige CA, Risk MJ, Sherwood OA, Jaap WC (2005) Clionid sponge surveys on the Florida Reef Tract suggest land-based nutrient inputs. Mar Pollut Bull 51:570-579

Weil E, Hernandez-Delgado EA, Bruckner AW, Ortiz AL, Nemeth MRH (2002) Distribution and status of Acroporid coral (Scleractinia) populations in Puerto Rico. In: Bruckner AW (ed) NOAA Tech Memo NMFS-OPR-24, p 71-98

Wheaton JL, Jaap WC (1988) Corals and other prominent benthic Cnidaria of Looe Key National Marine Sanctuary, Florida. Fla Mar Res Publ 43:1-25

Wilkinson C (ed) (2000) Status of coral reefs of the World: 2000 Vol 1. Global Coral Reef Monitoring Network. Australian Institute of Marine Science, Townsville

Williams DE, Miller MW (2012) Attributing mortality among drivers of population decline in Acropora palmata in the Florida Keys (USA). Coral Reefs 31:369-382

Williams DE, Miller MW, Kramer KL (2008) Recruitment failure in Florida Keys Acropora palmata, a threatened Caribbean coral. Coral Reefs 27:697-705

Wolff N, Grober-Dunsmore R, Rogers CS, Beets J (1999) Management implications of fish trap effectiveness in adjacent coral reef and gorgonian habitats. Environ Biol Fishes 55:81-90

> Woodley JD, Chornesky EA, Clifford PA, Jackson JBC and others (1981) Hurricane Allen's impact on Jamaican coral reefs. Science 214:749-755

Yoshioka PM, Yoshioka BB (1991) A comparison of the survivorship and growth of shallow-water gorgonian species of Puerto Rico. Mar Ecol Prog Ser 69:253-260

Zea S (1993) Cover of sponges and other sessile organisms in rocky and coral reef habitats of Santa Marta, Colombian Caribbean Sea. Caribb J Sci 29:75-88

Submitted: February 12, 2013; Accepted: May 30, 2013

Proofs received from author(s): August 12, 2013 